\title{
Lung blood flow studies in patients with scoliosis and neuromuscular weakness
}

\author{
W. A. LITTLER, S. R. REUBEN, and D. J. LANE \\ Cardiac Department and Nuffield Department of Clinical Medicine, Radcliffe Infirmary, Oxford
}

\begin{abstract}
Pulmonary capillary blood flow was measured by the nitrous oxide body plethysmograph technique in 16 patients, 10 of whom had scoliosis and six neuromuscular weakness.

A linear correlation was found between the pulmonary artery to capillary flow conduction time and $\mathrm{PaO}_{2}(\mathrm{r}=+0.85 ; \mathrm{P}<0.001)$.

The finding of a reduced flow conduction time and its correlation with the $\mathrm{PaO}_{2}$ suggests the presence of pulmonary arterial hypertension presumably on the basis of active vasoconstriction.
\end{abstract}

Chronic hypoxia irrespective of its cause is associated with a characteristic vascular pathology consisting of muscularization of the pulmonary arterioles, absence of medial hypertrophy in the muscular pulmonary arteries, and the presence of longitudinal muscle in the intima of arteries and arterioles (Hasleton, Heath, and Brewer, 1968).

The pathogenesis of cardiorespiratory failure in scoliosis has been described by Bergofsky, Turino, and Fishman (1959); the thoracic deformity leads to compression of the lungs and increases the work of breathing with consequential alveolar hypoventilation. Hypoxaemia so produced may be further increased by venous admixture resulting from inhomogeneity of alveolar ventilation and perfusion (Shaw and Read, 1960) and eventually leads to pulmonary arterial hypertension and right heart failure. This pulmonary arterial hypertension is due to an increased resistance to blood flow through the vascular bed rather than to mechanical obstruction of major blood vessels, to back pressure from the left atrium, or to increases in pulmonary blood flow (Bergofsky et al., 1959).

Lung capillary blood flow can be measured throughout the cardiac cycle using the $\mathrm{N}_{2} \mathrm{O}$-body plethysmograph method (Lee and DuBois, 1955) in which the rate of $\mathrm{N}_{2} \mathrm{O}$ uptake from the lungs is recorded continuously using an optical sensor and electropneumatic feedback transducer (Karatzas, Lee, and Stott, 1967). Analysis of the $\mathrm{N}_{2} \mathrm{O}$ uptake record provides the following information: (1) mean pulmonary blood flow; (2) the pulmonary artery to capillary flow conduction time, measured from the time of pulmonary valve opening to the foot of the pulmonary capillary flow pulse ; (3) the pulsatility of capillary blood flow (ratio of peak to mean flow rates).

Previous work (Reuben, 1970, 1971) has established a close relationship between flow conduction time and mean pulmonary artery pressure and between pulsatility of capillary blood flow and the pulmonary arterial time constant (the product of pulmonary arterial resistance and compliance).

In a series of experiments Reuben, Gersh, Swadling, and Lee (1970) induced hypoxia in animals and produced pulmonary arterial hypertension. Induced hypoxia also caused a significant decrease in pulmonary arterial compliance and pulmonary arterial distensibility while the pulmonary artery to pulmonary capillary flow conduction time was significantly reduced from the control value.

The present paper describes a study of lung capillary blood flow in patients with scoliosis or neuromuscular weakness with particular reference to the effect of hypoxia.

\section{METHODS}

Eighteen studies were performed on 16 patients who gave informed consent. The relevant clinical details are listed in Table I; all those patients who had had anterior poliomyelitis had required assisted ventilation during their acute illness.

Patient 5 was studied on three separate occasions: when she was severely hypoxic, a month later following intensive therapy, and, finally, six months later when she had maintained her improvement.

All patients were in sinus rhythm and none had evidence of airways obstruction (Table III). 
T A B LE I

DIAGNOSTIC AND ANTHROPOMETRIC DATA

\begin{tabular}{|c|c|c|c|c|c|c|c|c|c|}
\hline \multirow{2}{*}{ Case } & \multirow{2}{*}{ Age } & \multirow{2}{*}{ Sex } & \multirow{2}{*}{ BSA } & \multicolumn{4}{|c|}{ Scoliosis } & \multirow{2}{*}{$\begin{array}{l}\text { Site of Respiratory } \\
\text { Muscle Paralysis/ } \\
\text { Weakness }\end{array}$} & \multirow{2}{*}{ Grade of Dyspnoea ${ }^{\prime}$} \\
\hline & & & & $\begin{array}{l}\text { Direction of } \\
\text { Convexity }\end{array}$ & Aetiology & $\begin{array}{l}\text { Angle of } \\
\text { Curve }\end{array}$ & $\begin{array}{l}\text { Apex of } \\
\text { Curve }\end{array}$ & & \\
\hline $\begin{array}{l}1 \\
2 \\
3 \\
4 \\
5 \\
6 \\
7 \\
8 \\
8\end{array}$ & $\begin{array}{l}16 \\
24 \\
35 \\
15 \\
28 \\
21 \\
20 \\
21 \\
27\end{array}$ & $\begin{array}{l}\mathbf{F} \\
\mathbf{F} \\
\mathbf{F} \\
\mathbf{M} \\
\mathbf{F} \\
\mathbf{F} \\
\mathbf{M} \\
\mathbf{M} \\
\mathbf{M}\end{array}$ & $\begin{array}{l}1 \cdot 48 \\
1 \cdot 48 \\
1 \cdot 72 \\
1 \cdot 52 \\
1 \cdot 28 \\
1 \cdot 28 \\
1 \cdot 52 \\
1.43 \\
1 \cdot 66\end{array}$ & $\begin{array}{l}\text { Left } \\
\text { Right } \\
\text { Left } \\
\text { Left } \\
\text { Right } \\
\text { Right } \\
\text { Left } \\
\text { Left }\end{array}$ & $\begin{array}{l}\text { Idiopathic } \\
\text { Poliomyelitis } \\
\text { Poliomyelitis } \\
\text { Idiopathic } \\
\text { Poliomyelitis } \\
\text { Idiopathic } \\
\text { Poliomyelitis } \\
\text { Poliomyelitis } \\
\text { Poliomyelitis }\end{array}$ & $\begin{array}{r}70 \\
70 \\
60 \\
40 \\
110 \\
50 \\
65 \\
70\end{array}$ & $\begin{array}{ll}\mathrm{T} & 12 \\
\mathrm{~T} & 9 \\
\mathrm{~T} & 12 \\
\mathrm{~T} & 5 \\
\mathrm{~T} & 4 \\
\mathrm{~T} & 6 \\
\mathrm{~T} & 6 \\
\mathrm{~T} & 6\end{array}$ & $\begin{array}{l}\text { Right side } \\
\text { Right and left side } \\
\text { Right side } \\
\text { Left side } \\
\text { Left side }\end{array}$ & $\begin{array}{l}0 \\
2 \\
2 \\
0 \\
3 \\
1 \\
1 \\
1\end{array}$ \\
\hline $\begin{array}{l}10 \\
11 \\
12 \\
13\end{array}$ & $\begin{array}{l}41 \\
42 \\
40 \\
36 \\
34\end{array}$ & $\begin{array}{l}\mathbf{F} \\
\mathbf{F} \\
F\end{array}$ & $\begin{array}{l}1 \cdot 70 \\
1 \cdot 57 \\
1 \cdot 38 \\
1 \cdot 65\end{array}$ & $\begin{array}{c}\text { Left } \\
0 \\
0 \\
0\end{array}$ & $\begin{array}{l}\text { Poliomyelitis } \\
\text { Poliomyelitis } \\
\text { Poliomyelitis } \\
\text { Poliomyelitis }\end{array}$ & - & $\begin{array}{l}T \\
= \\
-\end{array}$ & $\begin{array}{l}\text { Left side } \\
\text { Bilateral } \\
\text { Bilateral } \\
\text { Bilateral }\end{array}$ & $\begin{array}{c}0 \\
0 \\
1 \\
\text { (Confined to a }\end{array}$ \\
\hline $\begin{array}{l}14 \\
15 \\
16\end{array}$ & $\begin{array}{l}59 \\
50 \\
37\end{array}$ & $\begin{array}{l}\mathbf{F} \\
\mathbf{M}\end{array}$ & $\begin{array}{l}1 \cdot 41 \\
1 \cdot 72 \\
1 \cdot 66\end{array}$ & $\begin{array}{l}\mathbf{0} \\
\mathbf{0} \\
\mathbf{0}\end{array}$ & $\begin{array}{c}\text { Poliomyelitis } \\
\text { Poliomyelitis } \\
\text { Muscular } \\
\text { dystrophy }\end{array}$ & 二 & $\overline{-}$ & $\begin{array}{l}\text { Bilateral } \\
\text { Bilateral } \\
\text { Bilateral }\end{array}$ & $\begin{array}{c}2-3 \\
1 \\
1\end{array}$ \\
\hline
\end{tabular}

I 0 No dyspnoea; 1 Dyspnoea with severe exertion; 2 Dyspnoea with moderate exertion; 3 Dyspnoea at rest.

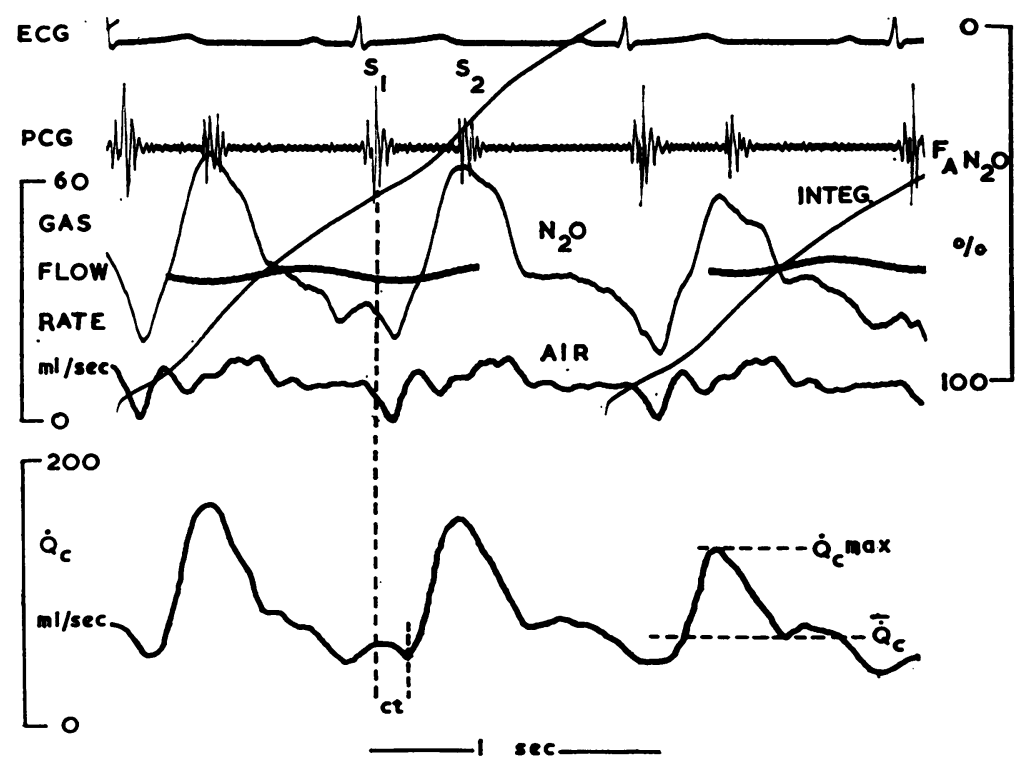

FIG. 1. Patient 2. Plethysmograph gas flow record. This is a composite figure in which the $\mathrm{N}_{2} \mathrm{O}$ trace has been superimposed over the AIR record from a cardiac cycle of equal length and a similar portion of the respiratory cycle. $E C G=$ electrocardiogram (Lead II); $\mathrm{PCG}=$ phonocardiogram; $\mathrm{N}_{2} \mathrm{O}=$ plethysmograph gas flow record during exhalation, following inhalation of $80 \% \mathrm{~N}_{2} \mathrm{O}$ in oxygen; AIR= plethysmograph gas flow record during exhalation following inhalation of air; $\dot{Q}_{c}$ represents the algebraic subtraction of $A I R$ from $\mathrm{N}_{2} \mathrm{O}$ for one cycle, calibrated in blood flow units; ct=pulmonary artery to capillary flow conduction time. INTEG $=$ the integrated signal of the $\mathrm{N}_{2} \mathrm{O}$ flow curve. 
Pulmonary capillary blood flow was measured by the $\mathrm{N}_{2} \mathrm{O}$ uptake technique during slow exhalation after a single breath of $80 \% \mathrm{~N}_{2} \mathrm{O}$ in $20 \% \mathrm{O}_{2}$ according to the method of Bosman et al. (1964). The plethysmograph optical sensor and electropneumatic feedback system with the relevant calibration details have been previously reported (Karatzas and Lee, 1969). The concentration of $\mathrm{N}_{2} \mathrm{O}$ in the expired gas was recorded continuously by an infrared $\mathrm{N}_{2} \mathrm{O}$ analyser (Beckman model LB-1) in closed circuit with the body plethysmograph.

Lead II of the electrocardiogram and a high frequency phonocardiogram from the pulmonary area were also obtained.

The pattern of instantaneous pulmonary capillary blood flow was derived from the $\mathrm{N}_{2} \mathrm{O}$ uptake in the manner previously described (Karatzas and Lee, 1969).

The patients were trained to perform the respiratory manoeuvres repeatedly in an identical manner and to maintain constant air flow during slow exhalation.

Pulmonary artery to capillary flow conduction time was measured as the time from the third major vibration of the first heart sound (indicating pulmonary valve opening) to the foot of the capillary flow pulse (Fig. 1). The normal range in this laboratory is 120-180 msec. In patients in sinus rhythm no difficulty is encountered in delineating the foot of the pulmonary capillary flow pulse, and measurements made by different observers usually agreed within 10 msec.

The pulsatility index of capillary blood flow was calculated as the ratio of peak to mean flow rates. Normal in this laboratory is $1 \cdot 8-2 \cdot 0: 1$.

Lung function tests were performed on the same day as the plethysmograph studies. These included: (1) forced vital capacity (FVC) and forced expiratory volume in one second $\left(F^{2} V_{1}\right)$ using a Med-Science Wedge spirometer which had a digital readout; (2) total lung capacity (TLC) using the nitrogen washout technique ; (3) arterial blood was drawn anaerobically from the brachial artery and blood gas tensions were measured with Radiometer electrodes and corrected for elapsed time and temperature according to the nomogram of Kelman and Nunn (1966); (4) expired air was collected over a 5-minute period and analysed for oxygen and carbon dioxide tensions. The ratio of physiological dead space to tidal volume (VD/VT) was calculated from the arterial blood and expired air carbon dioxide tensions (Comroe et al., 1962) ; (5) the degree of venous admixture was calculated assuming an arterial-mixed venous oxygen extraction of $4.5 \mathrm{ml} / 100 \mathrm{ml}$.

\section{RESULTS}

Table II summarizes the results of the lung capillary blood flow studies. Figure 2 is a graph of pulmonary artery to capillary conduction time plotted against $\mathrm{PaO}_{2}$. The relationship is a linear one and demonstrates that those patients with the lowest $\mathrm{PaO}_{2}$ have the shortest flow conduction time. The regression equation obtained was:

$$
\mathrm{CT}=1.47 \mathrm{PaO}_{2}-15.39
$$

Correlation coefficient $=+0.85 ; \mathrm{P}<0.001$.

The results of the lung function studies are summarized in Table III.

\section{T A B L E I I}

\section{$\mathrm{N}_{2} \mathrm{O}$-PLETHYSMOGRAPH RESULTS}

\begin{tabular}{|c|c|c|c|c|}
\hline Case & $\begin{array}{c}\text { Heart } \\
\text { Rate } \\
\text { (beats/ } \\
\text { min) }\end{array}$ & $\begin{array}{c}\text { Pulmonary } \\
\text { Blood } \\
\text { Flow } \\
\text { (1./min) }\end{array}$ & $\begin{array}{c}\text { Pulmonary } \\
\text { Artery- } \\
\text { Capillary } \\
\text { Flow } \\
\text { Conduction } \\
\text { Time (msec) }\end{array}$ & $\begin{array}{c}\text { Pulsatility } \\
\text { Index }\end{array}$ \\
\hline $\begin{array}{c}1 \\
2 \\
3 \\
4 \\
5 a \\
\\
\\
6 \\
7 \\
8 \\
9 \\
10 \\
11 \\
12 \\
13 \\
14 \\
15 \\
16\end{array}$ & $\begin{array}{r}90 \\
96 \\
72 \\
72 \\
96 \\
94 \\
90 \\
92 \\
96 \\
72 \\
96 \\
80 \\
72 \\
80 \\
120 \\
100 \\
100 \\
80\end{array}$ & $\begin{array}{l}6 \cdot 1 \\
2 \cdot 8 \\
4 \cdot 1 \\
5 \cdot 8 \\
2 \cdot 0 \\
2 \cdot 7 \\
2 \cdot 9 \\
2 \cdot 5 \\
2 \cdot 5 \\
3 \cdot 5 \\
3 \cdot 3 \\
6 \cdot 4 \\
4 \cdot 3 \\
4 \cdot 0 \\
2 \cdot 5 \\
3 \cdot 2 \\
5 \cdot 6 \\
3 \cdot 0\end{array}$ & $\begin{array}{r}126 \\
105 \\
85 \\
104 \\
60 \\
80 \\
75 \\
140 \\
125 \\
110 \\
112 \\
137 \\
100 \\
120 \\
99 \\
70 \\
125 \\
120\end{array}$ & $\begin{array}{l}1 \cdot 9 \\
2.4 \\
1 \cdot 9 \\
2 \cdot 1 \\
1 \cdot 7 \\
1 \cdot 7 \\
1.8 \\
2.4 \\
2 \cdot 1 \\
2 \cdot 0 \\
2 \cdot 0 \\
2 \cdot 0 \\
2 \cdot 0 \\
2 \cdot 2 \\
2 \cdot 1 \\
1 \cdot 8 \\
2 \cdot 0 \\
2 \cdot 0\end{array}$ \\
\hline Mean \pm S.E. & $89 \pm 13$ & $3 \cdot 80 \pm 1 \cdot 5$ & $104 \cdot 3 \pm 23 \cdot 7$ & $2 \cdot 0 \pm 0 \cdot 2$ \\
\hline
\end{tabular}

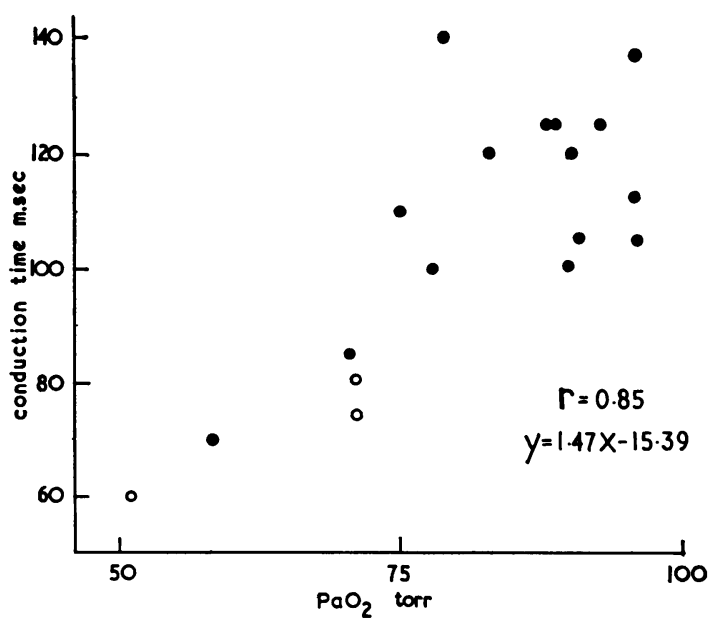

FIG. 2. Relationship between pulmonary artery to capillary flow conduction time (ordinate) and $\mathrm{PaO}_{2}$ (abscissa). Each point on the graph represents the average data for each patient. The three open circles represent the findings in patient 5 on three separate occasions. 


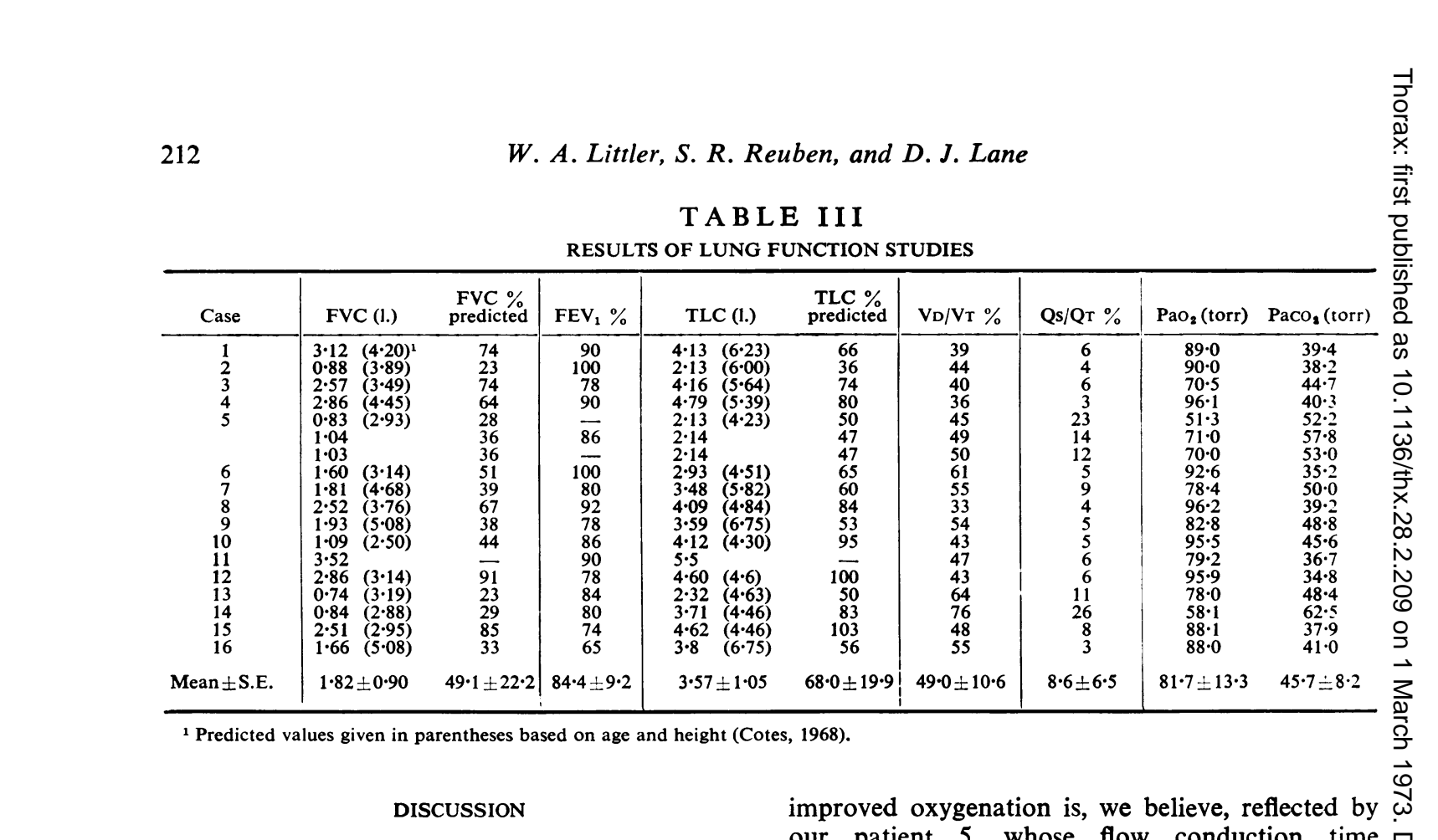

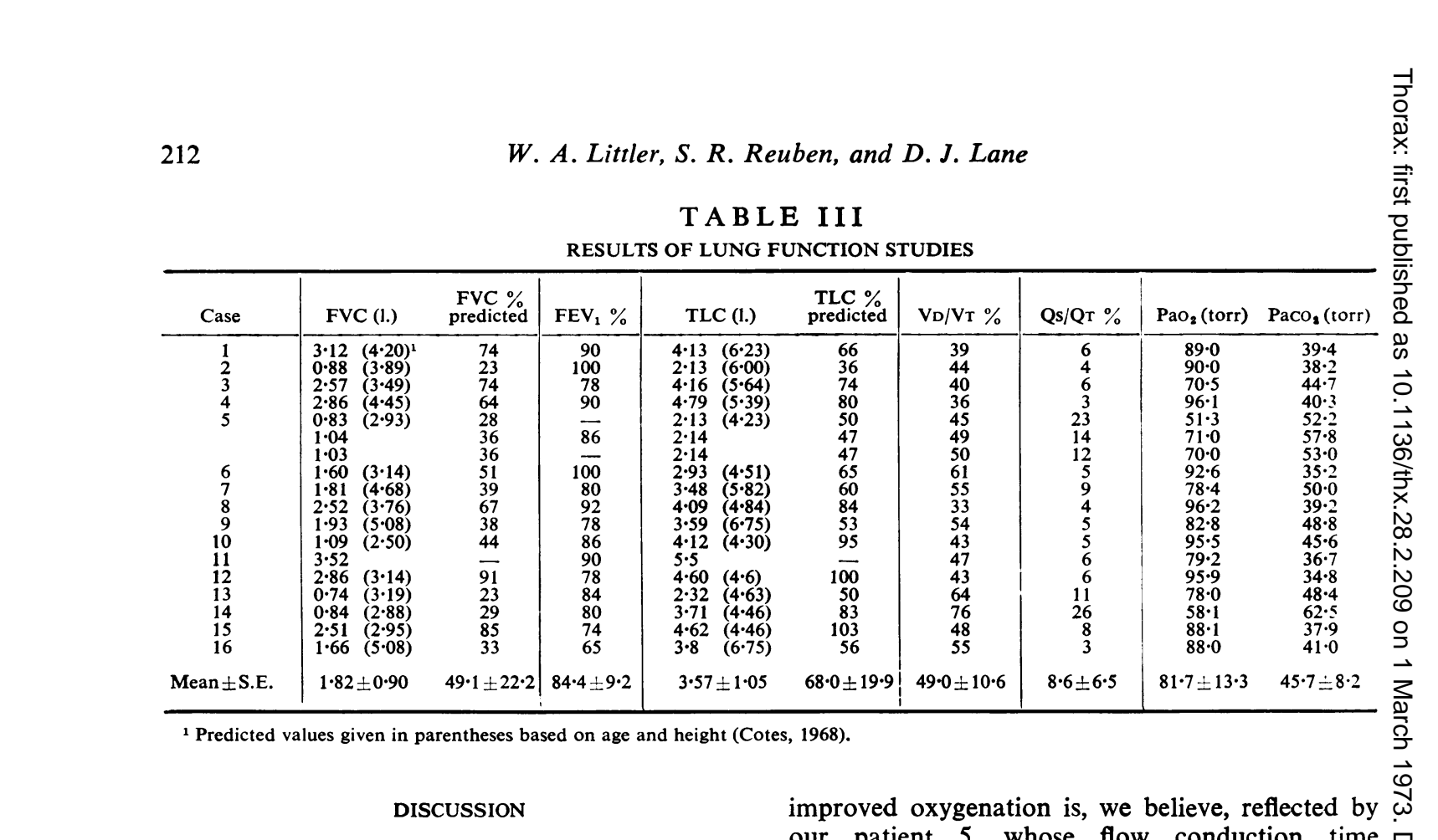

\begin{tabular}{|c|c|c|c|c|c|c|c|c|c|}
\hline Case & FVC (1.) & $\begin{array}{c}\text { FVC \% } \\
\text { predicted }\end{array}$ & FEV $_{1} \%$ & TLC (1.) & $\begin{array}{l}\text { TLC \% } \\
\text { predicted }\end{array}$ & VD/VT \% & Qs/QT \% & $\mathrm{PaO}_{2}$ (torr) & $\mathrm{PaCO}_{2}$ (torr) \\
\hline $\begin{array}{l}1 \\
2 \\
3 \\
4 \\
5 \\
\\
6 \\
7 \\
8 \\
9 \\
10 \\
11 \\
12 \\
13 \\
14 \\
15 \\
16\end{array}$ & $\begin{array}{ll}3.12 & (4.20)^{1} \\
0.88 & (3.89) \\
2.57 & (3.49) \\
2.86 & (4.45) \\
0.83 & (2.93) \\
1.04 & \\
1.03 & \\
1.60 & (3.14) \\
1.81 & (4.68) \\
2.52 & (3.76) \\
1.93 & (5.08) \\
1.09 & (2.50) \\
3.52 & \\
2.86 & (3.14) \\
0.74 & (3.19) \\
0.84 & (2.88) \\
2.51 & (2.95) \\
1.66 & (5.08)\end{array}$ & $\begin{array}{l}74 \\
23 \\
74 \\
64 \\
28 \\
36 \\
36 \\
51 \\
39 \\
67 \\
38 \\
44 \\
91 \\
23 \\
29 \\
85 \\
33\end{array}$ & $\begin{array}{r}90 \\
100 \\
78 \\
90 \\
86 \\
100 \\
80 \\
92 \\
78 \\
86 \\
90 \\
78 \\
84 \\
80 \\
74 \\
65\end{array}$ & $\begin{array}{ll}4 \cdot 13 & (6 \cdot 23) \\
2 \cdot 13 & (6 \cdot 00) \\
4 \cdot 16 & (5 \cdot 64) \\
4 \cdot 79 & (5 \cdot 39) \\
2 \cdot 13 & (4 \cdot 23) \\
2 \cdot 14 & \\
2 \cdot 14 & \\
2 \cdot 93 & (4 \cdot 51) \\
3 \cdot 48 & (5 \cdot 82) \\
4 \cdot 09 & (4 \cdot 84) \\
3 \cdot 59 & (6 \cdot 75) \\
4 \cdot 12 & (4 \cdot 30) \\
5 \cdot 5 & \\
4 \cdot 60 & (4 \cdot 6) \\
2 \cdot 32 & (4 \cdot 63) \\
3 \cdot 71 & (4 \cdot 46) \\
4 \cdot 62 & (4 \cdot 46) \\
3 \cdot 8 & (6 \cdot 75)\end{array}$ & $\begin{array}{r}66 \\
36 \\
74 \\
80 \\
50 \\
47 \\
47 \\
65 \\
60 \\
84 \\
53 \\
95 \\
100 \\
50 \\
83 \\
103 \\
56\end{array}$ & $\begin{array}{l}39 \\
44 \\
40 \\
36 \\
45 \\
49 \\
50 \\
61 \\
55 \\
33 \\
54 \\
43 \\
47 \\
43 \\
64 \\
76 \\
48 \\
55\end{array}$ & $\begin{array}{r}6 \\
4 \\
6 \\
3 \\
23 \\
14 \\
12 \\
5 \\
9 \\
4 \\
5 \\
5 \\
6 \\
6 \\
11 \\
26 \\
8 \\
3\end{array}$ & $\begin{array}{l}89 \cdot 0 \\
90 \cdot 0 \\
70 \cdot 5 \\
96 \cdot 1 \\
51 \cdot 3 \\
71 \cdot 0 \\
70 \cdot 0 \\
92 \cdot 6 \\
78 \cdot 4 \\
96 \cdot 2 \\
82 \cdot 8 \\
95 \cdot 5 \\
79 \cdot 2 \\
95 \cdot 9 \\
78 \cdot 0 \\
58 \cdot 1 \\
88 \cdot 1 \\
88 \cdot 0\end{array}$ & $\begin{array}{l}39 \cdot 4 \\
38 \cdot 2 \\
44 \cdot 7 \\
40 \cdot 3 \\
52 \cdot 2 \\
57 \cdot 8 \\
53 \cdot 0 \\
35 \cdot 2 \\
50 \cdot 0 \\
39 \cdot 2 \\
48 \cdot 8 \\
45 \cdot 6 \\
36 \cdot 7 \\
34 \cdot 8 \\
48 \cdot 4 \\
62 \cdot 5 \\
37 \cdot 9 \\
41 \cdot 0\end{array}$ \\
\hline Mean \pm S.E. & $1.82 \pm 0.90$ & $49 \cdot 1 \pm 22 \cdot 2$ & $84 \cdot 4 \pm 9 \cdot 2$ & $3 \cdot 57 \pm 1 \cdot 05$ & $68 \cdot 0 \pm 19 \cdot 9$ & $49 \cdot 0 \pm 10 \cdot 6$ & $8 \cdot 6 \pm 6 \cdot 5$ & $81 \cdot 7 \pm 13 \cdot 3$ & $45 \cdot 7 \doteq 8 \cdot 2$ \\
\hline
\end{tabular}

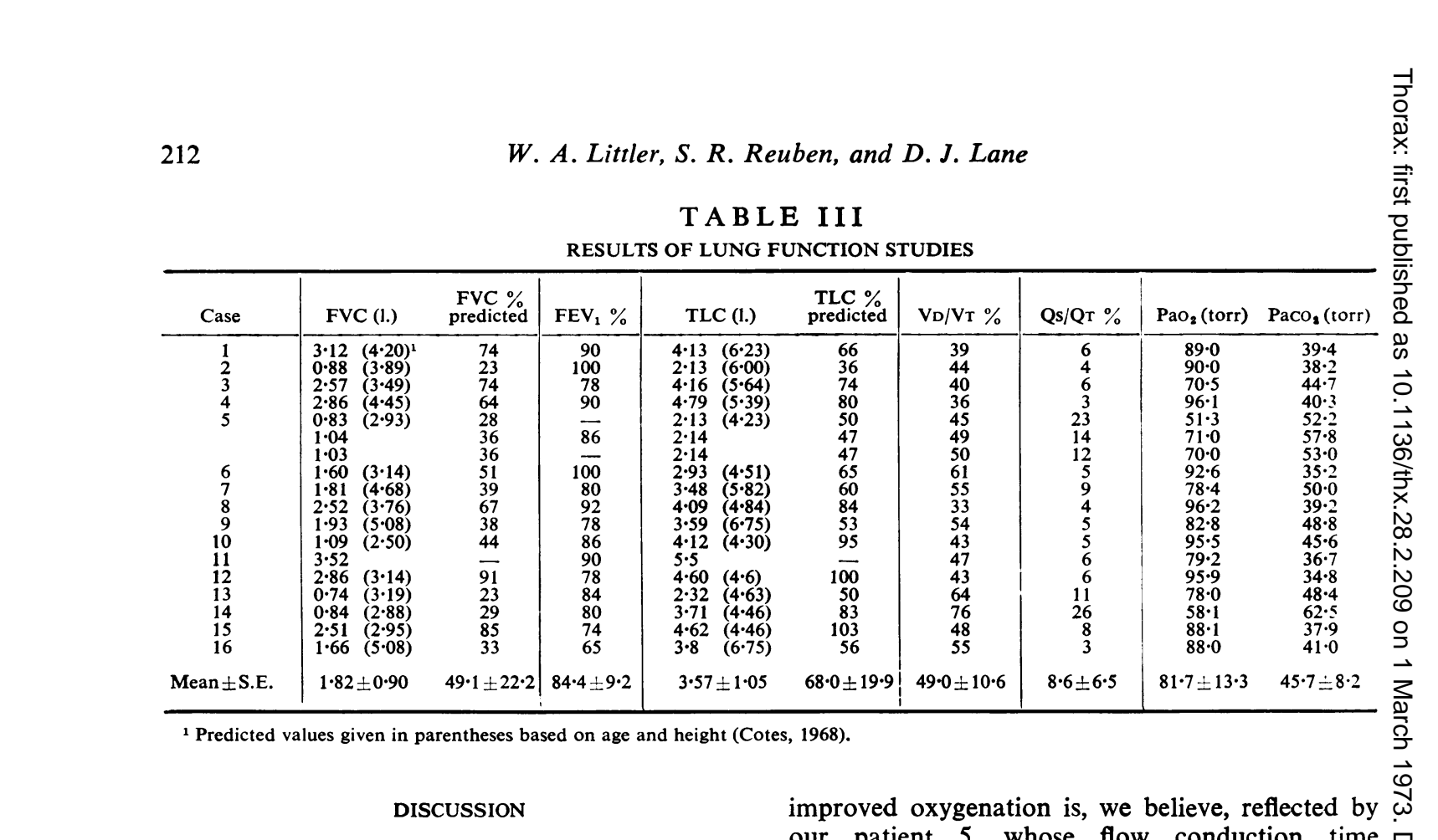

Our results show a linear relationship between the pulmonary artery to capillary flow conduction time and the $\mathrm{PaO}_{2}$; those patients with the shortest conduction times had the severest degree of hypoxaemia. The flow conduction time depends on the distensibility of the pulmonary arterial system and we believe that the shortened conduction time found in these patients is due to reduced arterial distensibility. Reuben (1970) has demonstrated a close correlation between the pulmonary artery to capillary flow conduction time and the mean pulmonary arterial pressure in patients with valvular heart disease and also in patients with normal pulmonary arterial pressures. The relationship was an inverse curvilinear one; patients with the severest degree of pulmonary arterial hypertension had the shortest flow conduction time. It is possible that decreased pulmonary arterial distensibility in the absence of pulmonary arterial hypertension is due to vasomotor activity of the smooth muscles of the pulmonary arteries.

Clinical and experimental studies have demonstrated a close correlation between hypoxia and pulmonary arterial hypertension. This correlation has been found in normal people living at high altitude (Peñaloza, Sime, Banchero, and Gamboa, 1963) or when rendered acutely hypoxic (Fishman, Fritts, and Cournand, 1960) as well as in patients with emphysema (Whitaker, 1954) and scoliosis (Bergofsky et al., 1959). There is evidence that hypoxic pulmonary arterial hypertension is reversible (Whitaker, 1954; Bergofsky et al., 1959; Peñaloza et al., 1963). Such reversibility due to

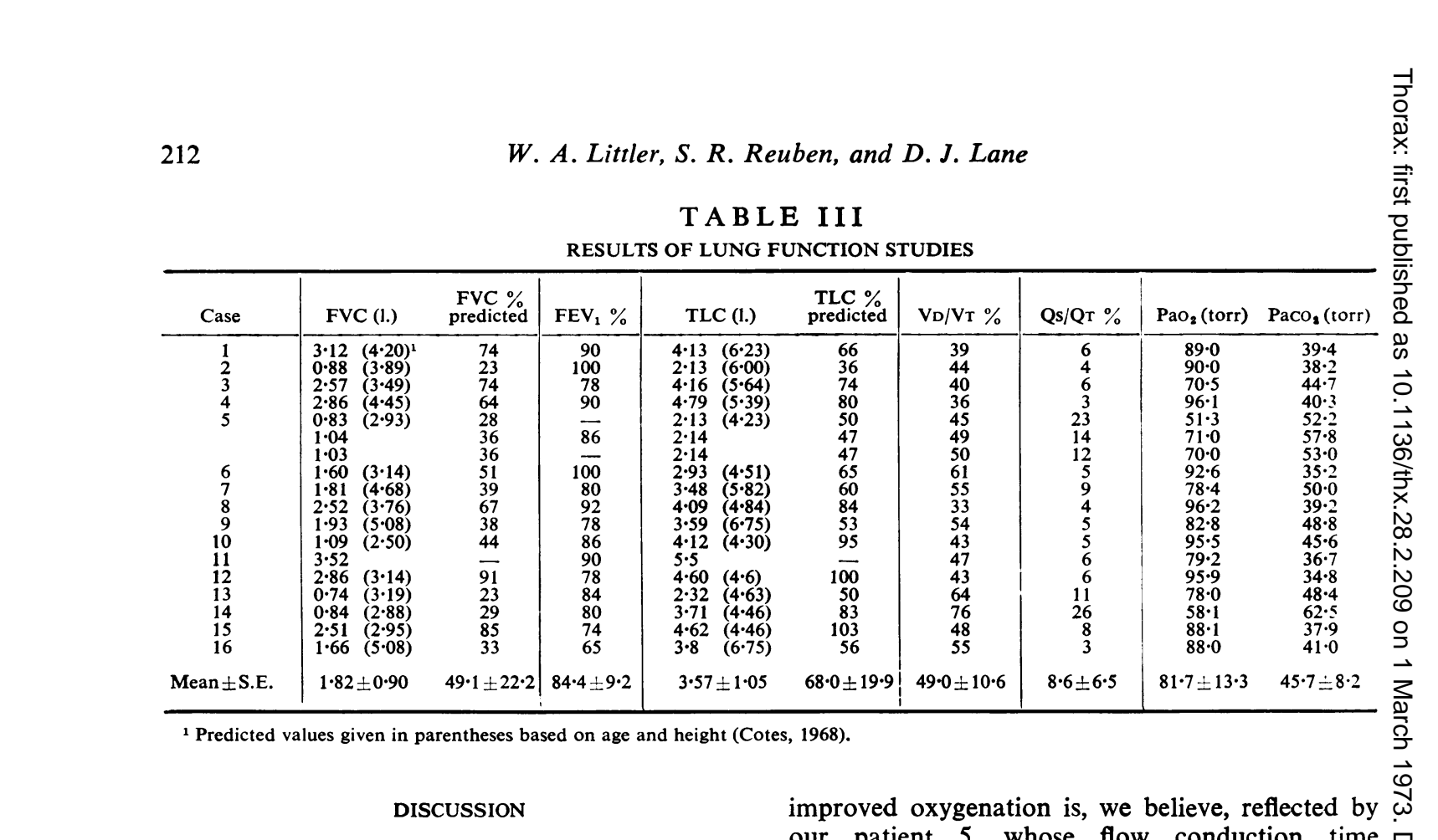
lengthened from 60 to $80 \mathrm{msec}$ when the $\mathrm{PaO}_{2}$ was raised from 52 to 70 torr with vigorous therapy. This finding is in keeping with the results of Bergofsky and his colleagues, who lowered the mean pulmonary artery pressure from 52 to $18 \mathrm{mmHg}$ in a scoliotic patient by positive pressure ventilation.

Three scoliotic patients $(2,4$, and 8$)$ had a shortened flow conduction time $(105,104$ and 110 msec respectively) despite normal blood gas tensions. Hanley, Platts, Clifton, and Morris (1958) demonstrated a raised pulmonary artery pressure in the absence of hypoxia in one scoliotic 3 patient while the pulmonary vessels of two of their patients dying from 'kyphoscoliotic heart disease' did not show the histological changes commonly associated with severe pulmonary arterial hypertension. Bergofsky and his col- $\frac{7}{0}$ leagues (1959) also found a raised pulmonary artery pressure in the absence of hypoxia in certain $\mathcal{N}$ scoliotics, although when hypoxia was present the $N$ pulmonary arterial hypertension was always more N severe. These authors suggested that "compression, diminution in distensibility and distortion of the pulmonary vessels due to the small deformed $\stackrel{O}{E}$ lungs may produce a raised pulmonary arterial $\stackrel{\mathbb{D}}{\circ}$ pressure'. It is interesting to note that our three patients $(2,4$, and 8$)$ did not have a great reduction in their total lung capacity $\left(66,89\right.$, and $84 \% \frac{\mathbb{D}}{\circ}$ of predicted normal respectively). However, it is $\frac{\rho}{\mathbb{D}}$ possible that the distensibility of the vessels may $\varrho$ have been altered by the distortion of the lungs.

Lung capillary blood flow is pulsatile with each 8

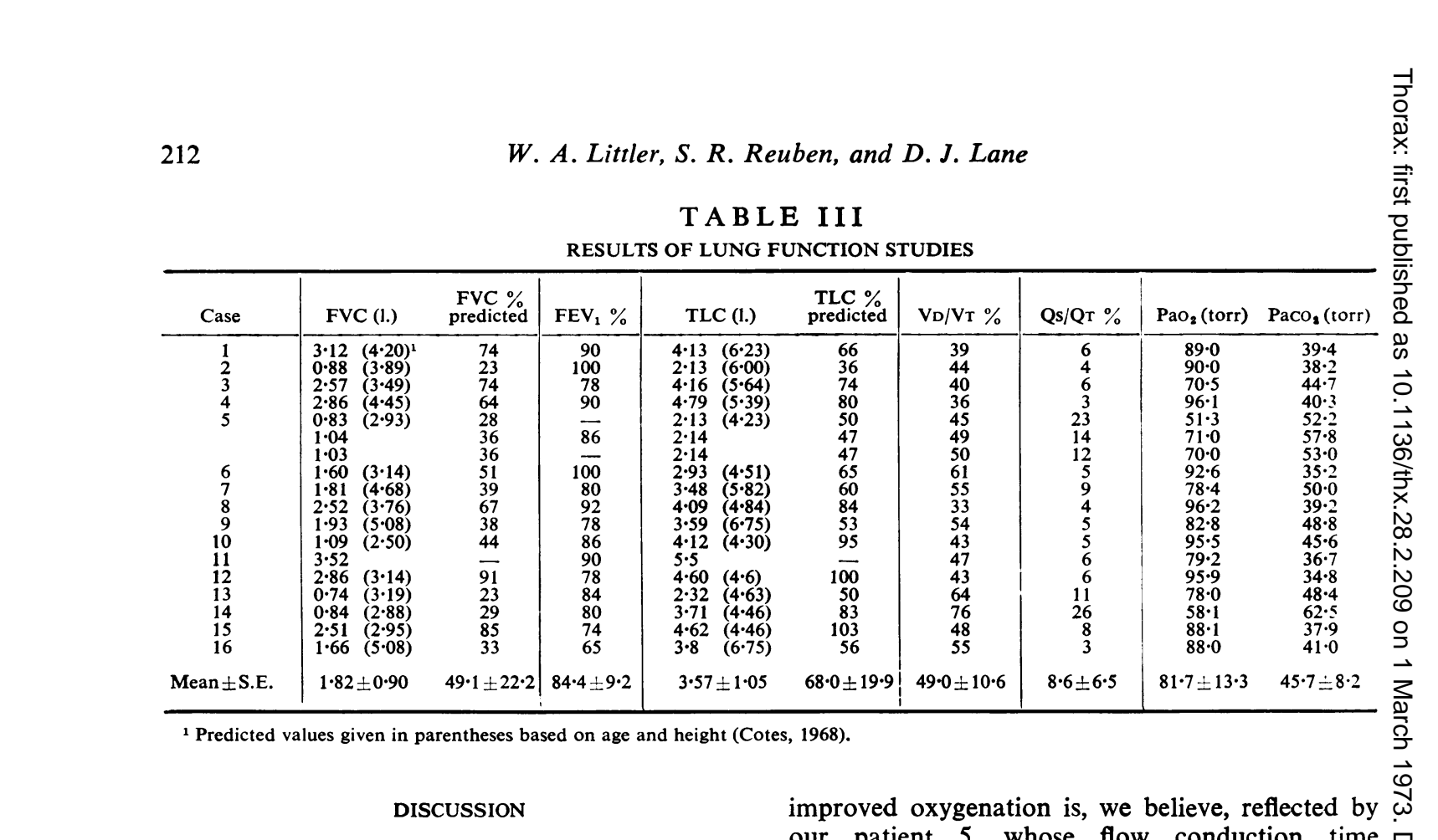

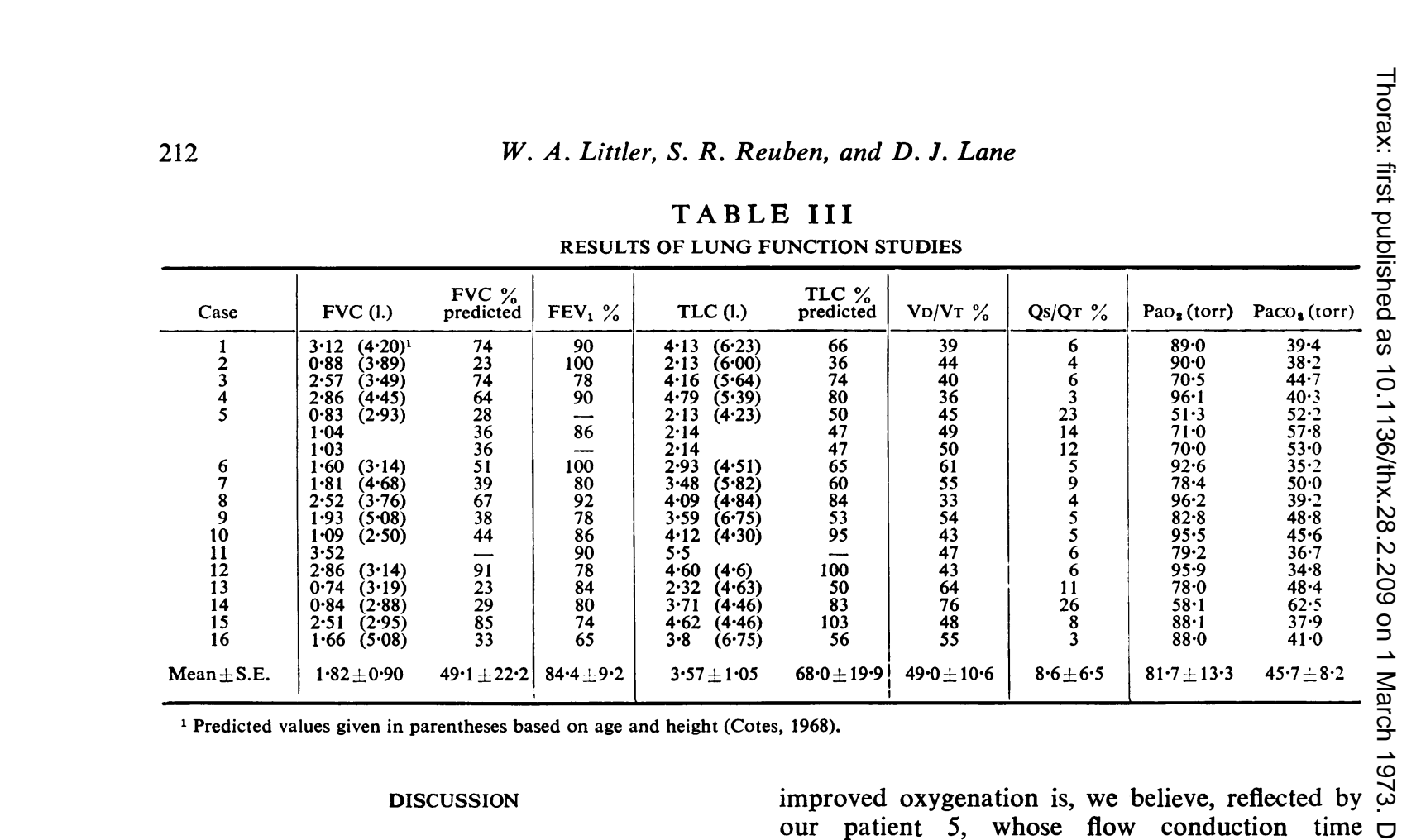

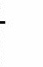

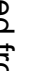

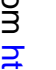

$$
\text { s.t. }
$$


heart beat (Lee and DuBois, 1955). Karatzas and Lee (1970) have shown that in patients with valvular heart disease the pattern of capillary blood flow is influenced by both pulmonary arterial and venous resistance as well as heart rate. Studies of the effect of acute hypoxia on the capillary flow profile in dogs have shown that there was no significant difference between values of the pulsatility index of the control state and hypoxia (Morkin, Levine, and Fishman, 1964 ; Reuben et al., 1970).

The pulsatility index of capillary blood flow in our patients was normal. We believe that this was because the reduction in pulmonary arterial distensibility (as indicated by the reduced flow conduction time) compensated for the raised pulmonary vascular resistance (which we did not measure but assumed was present) and so maintained a uniform time constant. This uniformity of the time constant explains the finding of a normal pulsatility index (Reuben, 1971).

Wasserman, Butler, and Van Kessel (1966) and Karatzas and Lee (1969) showed an inverse relationship between pulsatility of capillary blood flow and heart rate. However, normal pulsatility was maintained up to rates of 100 beats per minute. Only one of our patients had a rate greater than 100 (120 per minute) and she maintained a normal pulsatility. No measurement of pulmonary venous pressure was made in any of our patients ; however, from the work of Bergofsky et al. (1959) it is unlikely that it would be raised in these patients.

Abnormal ventilation-perfusion relationships will clearly affect the accuracy of the $\mathrm{N}_{2} \mathrm{O}$ plethysmograph method when used for estimating the pulmonary blood flow. This would explain the low values found in some of our patients. Bergofsky did not find any extraordinary increases in pulmonary blood flow at rest which could account for a raised pulmonary arterial pressure in his group of scoliotic patients.

We conclude that in our patients the reduced pulmonary artery to capillary flow conduction time and normal pulsatility of capillary flow is due to pulmonary arterial hypertension and reflect the vasoconstrictive effects of hypoxia on their pulmonary arterioles. The $\mathrm{N}_{2} \mathrm{O}$ plethysmograph technique could prove a useful non-invasive method for studying the severity of such changes and in assessing the response to treatment.

We wish to thank Professor Duthie for allowing us to study patients who were under his care. We are indebted to Mrs. E. Wheeler, Mr. T. Stallard, Miss C. Ranson, and Dr. B. Hasleman for technical assistance and to Dr. G. de J. Lee who allowed us to use the facilities of his laboratory.

\section{REFERENCES}

Bergofsky, E. H., Turino, G. M., and Fishman, A. P. (1959). Cardiorespiratory failure in kyphoscoliosis. Medicine (Baltimore), 38, 263.

Bosman, A. R., Honour, A. J., Lee, G. de J., Marshall, R., and Stott, F. D. (1964). A method for measuring instantaneous pulmonary capillary blood flow and right ventricular stroke volume in man. Clin. Sci., 26, 247.

Comroe, J. H. Jr., Forster, R. E., DuBois, A. B., Briscoe, W. A., and Carlsen, E. (1962). The Lung., 2nd ed. Year Book Medical Publishers, Chicago.

Cotes, J. E. (1968). Lung Function, 2nd ed. Blackwell, Oxford.

Fishman, A. P., Fritts, H. W. Jr., and Cournand, A. (1960). Effects of acute hypoxia and exercise on the pulmonary circulation. Circulation, 22, 204.

Hanley, T., Platts, M. M., Clifton, M., and Morris, T. L. (1958). Heart failure of the hunchback. Quart. J. Med., 27 (n.s.), 155.

Hasleton, P. S., Heath, D., and Brewer, D. B. (1968). Hypertensive pulmonary vascular disease in states of chronic hypoxia. J. Path. Bact., 95, 431.

Karatzas, N. B., and Lee, G. de J. (1969). Propagation of blood flow pulse in the normal human pulmonary arterial system. Circulat. Res., 25, 11.

- and - (1970). Instantaneous lung capillary blood flow in patients with heart disease. Cardiovasc. Res., 4, 265.

$\longrightarrow,-$, and Stott, F. D. (1967). A new electropneumatic flowmeter for the body plethysmograph.J. appl. Physiol., 23, 276.

Kelman, G. R., and Nunn, J. F. (1966). Nomograms for correction of blood, $\mathrm{PO}_{2}, \mathrm{PCO}_{2}, \mathrm{pH}$, and base excess for time and temperature. J. appl. Physiol., 21, 1484.

Lee, G. de J., and DuBois, A. B. (1955). Pulmonary capillary blood flow in man. J. clin. Invest., 34, 1380.

Morkin, E., Levine, R. O., and Fishman, A. P. (1964). Pulmonary capillary flow pulse and the site of pulmonary vasoconstriction in the dog. Circulat. Res., 15, 146.

Peñaloza, D., Sime, F., Banchero, N., and Gamboa, R. (1963). Pulmonary hypertension in healthy man born and living at high altitudes. In: Normal and Abnormal Pulmonary Circulation: Fifth Conference on Research in Emphysema, Aspen, Colorado, 1962, edited by R. F. Grover. Med. thorac., 19, 449.

Reuben, S. R. (1970). Wave transmission in the pulmonary arterial system in disease in man. Circulat. Res., 27, 523. (1971). Compliance of the human pulmonary arterial system in disease. Circulat. Res., 29, 40.

- Gersh, B. J., Swadling, J. P., and Lee, G. de J. (1970). Measurement of pulmonary arterial distensibility in the dog. Cardiovasc. Res., 4, 473.

Shaw, D. B., and Read, J. (1960). Hypoxia and thoracic scoliosis. Brit. med. J., 2, 1486.

Wasserman, K., Butler, J., and Van Kessel, A. (1966). Factors affecting the pulmonary capillary flow pulse in man. J. appl. Physiol., 21, 890.

Whitaker, W. (1954). Pulmonary hypertension in congestive heart failure complicating chronic lung disease. Quart. J. Med., (n.s.), 23, 57. 